\title{
Effectiveness of Asymmetrical Veneering with Hardwood Species of Varying Shrinkage and Porosity
}

\section{Učinkovitost asimetričnog furniranja furnirom tvrdih vrsta drva različitog utezanja i poroznosti}

\author{
Original scientific paper • Izvorni znanstveni rad \\ Received-prispjelo: 11. 3. 2013. \\ Accepted-prihvaćeno: 9. 4. 2014. \\ UDK: $630 * 832.281 .1 ; 630 * 812.23$ \\ doi:10.5552/drind.2014.1315
}

\begin{abstract}
The aim of the study was to check deformations of asymmetrically veneered panels using glue with elastic bonding. In order to achieve the aim, a special stand was designed to analyse the geometry of furniture elements. It is known that boards became convex after veneering with rigid glue. However, the level of deformations for varying parameters of veneering was not equal. As the result of veneering with elastic glue, the boards preserved their primary shape. In any case, the level of deformation depended on wood veneer species. The deformation of the boards was not influenced by their shrinkage. It is supposed that the main influence is the difference in porosity.
\end{abstract}

Keywords: asymmetrical veneering, wood-based panels, deformations, shrinkage, porosity

SAŽETAK • Cilj istraživanja bio je provjeriti deformacije asimetrično furniranih panela primjenom elastičnog ljepila. Da bi se postigao cilj, dizajniran je poseban stalak za analizu geometrije dijelova namještaja. Poznato je da nakon furniranja primjenom krutog ljepila ploče postanu konveksne. Međutim, razina deformacija za različite parametre furniranja nije jednaka. Nakon furniranja primjenom elastičnog ljepila ploče su očuvale svoj primarni oblik. U svakom slučaju, razina deformacije ovisi o vrsti drva furnira. Na deformaciju ploče ne utječe utezanje ploče. Pretpostavlja se da najveći utjecaj na deformacije ploča ima poroznost drva.

Ključne riječi: asimetrično furniranje, ploče na bazi drva, deformacije, utezanje

\section{INTRODUCTION}

1. UVOD

Veneering is one of the most important processes in today's furniture industry. The only fully recognised, tried and tested method is symmetrical veneering. In industry, the process of asymmetrical veneering was applied a long time ago (Hayward, 1949), but now is only used occasionally. On the one hand, it leads to cheaper products and production (Ostrowski and Roszkowski, 2009), but on the other hand, it causes warp of furniture elements. An analysis of deformation is espe-

\footnotetext{
${ }^{1}$ Authors are Ph.D. student, student, assistant and professor at Faculty of Wood Technology, Warsaw University of Life Sciences, Warsaw, Poland.

Autori su doktorand, student, asistent i profesor Fakulteta drvne tehnologije, Sveučilište bioloških znanosti u Varšavi, Varšava, Poljska.
} 
cially important when composite materials are taken into consideration (Negri et al., 2009). Asymmetrically veneered wood-based panels, used as furniture elements, are composites consisting of materials of different physical and chemical properties glued together. Therefore, the glue is the key to finding a solution to avoid deformations in the composites.

Industrial asymmetrical veneering is currently done intuitively. Obviously, it would be better if this method was supported with the results of studies. The purpose of the initial experiments was to find an adhesive that would bond veneer and board without causing significant geometric deformations in asymmetrical veneering. In order to achieve it, samples were veneered only on one side using 5 industrial and 1 experimental glue (Olenska et al., 2010; Olenska et al., $2011 \mathrm{a}, \mathrm{b}$ ). The present research showed that samples, asymmetrically veneered using rigid glue bonds, had a general tendency to become deformed. However, the properties of the glue are the most important factor affecting the level of geometric deformations of the board. The main conclusion from the preliminary studies is that it is possible to avoid casting asymmetrically veneered panels by using an elastic bonding adhesive. Therefore, the following research was performed with this type of glue. Primary research showed the importance of shrinkage on asymmetrical veneering (Olenska et al., 2011c), and therefore extended research was continued.

The aim of our studies was to analyse the influence of species of different shrinkage on the geometric stability of furniture elements in asymmetrical veneering. Boards were veneered on both large sides or on only one large side using an elastic bonding adhesive.

\section{MATERIALS AND METHODS}

\section{MATERIJAL I METODE}

Measurements were done on a specially designed stand. The stand is composed of elements as shown in Figure 1.

The main idea of the stand is to define a reference virtual plane (1). This plane is created with four pegs.

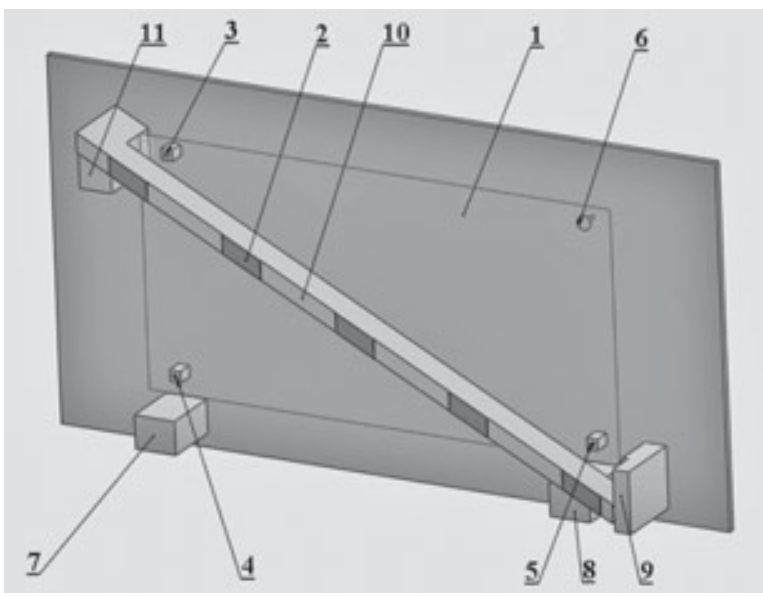

Figure 1 The scheme of the measurement station (explanation in the text)

Slika 1. Shema mjerenja (opis u tekstu)
Three of them have a constant height of $30 \mathrm{~mm}(3,4,5)$. The fourth is adjustable (6) in order to avoid deflection of the sample, which is attached to the pegs. The force is axially positioned with pegs. During measurements, panels are always placed equally in position to each peg. The position of the panels is secured with three fixed blocks $(7,8,9)$. The visible surface of the strip (10) forms the reference surface. The strip is placed with three blocks $(8,9,11)$. The distance between the reference virtual plane and reference surface of the strip is constant. This is where the measured board is placed. The geometry is measured in five areas (2), five times in each area (3 mm gap) with a depth gauge. Its precision is $0.01 \mathrm{~mm}$, and measurement error is $0.02 \mathrm{~mm}$.

Four samples of the dimensions of $900 \times 450 \mathrm{~mm}$ and $18 \mathrm{~mm}$ thick were veneered in the same way. After veneering, boards were conditioned at $20 \pm 2{ }^{\circ} \mathrm{C}$ and 65 $\pm 5 \%$ relative humidity for seven days. All the boards were measured in three states, as follows: unveneered board, unvarnished asymmetrically veneered board and varnished asymmetrically veneered board.

For choosing veneer pairs (each on one large side), a comparison was made of the linear shrinkage values of wood species. Contractions in volume for the used veneers are as follows: Beech (Fagus sylvatica L.) - $11.8 \%$, African ebony (Diospyros spp. Hiern) $12.8 \%$, Macassar ebony (Diospyros celebica Bakh.) $5.1 \%$ (EN 13556; Kokocinski, 2004). Porosity was defined basing on wood density according to standard equation (Kokocinski, 2004): porosity of African ebony $-20 \%$, porosity of beech $-55 \%$ and porosity of Macassar ebony.

Studies were divided into three steps of different shrinkage value: 1 - small difference of shrinkage values: $11.8 / 12.8 \%, 2$ - significant difference of shrinkage values: $5.1 / 11.8 \%$ and 3 - large difference of shrinkage values: $11.8 / 0 \%$.

All the boards were veneered using the same type of elastic bonding glue with the following characteristics: viscosity $2.5 \mathrm{~Pa} \cdot \mathrm{s}$, density $0.80 \mathrm{~g} / \mathrm{cm}^{3}$, Young modoulus $2480 \mathrm{MPa}$ (Papadopoulos et al., 2002; Konnerth and Gindl, 2006), Poisson's ratio 0.3 (Konnerth et al., 2007), contact angle $81^{\circ}$ (Olenska et al., 2012) and spread $150 \mathrm{~g} / \mathrm{m}^{2}$. Linear shrinkage - $1.4 \%$ and volume shrinkage $-4.2 \%$ of glue were measured according to the method of Jakubiak and Linden (2001). Shore's hardness - 51 HD was measured according to PN- EN ISO 868: 2005P and ISO 7619-1. In addition, the following parameters of veneering were constant: pressure $1.5 \mathrm{MPa}$, temperature $22^{\circ} \mathrm{C}$, time $240 \mathrm{~min}$.

\section{RESULTS AND DISCUSSION}

\section{REZULTATI I RASPRAVA}

Figures 2 and 3 show as follows:

- - difference between unveneered board and board veneered on both sides, unvarnished,

- - difference between unveneered board and board veneered on both sides, varnished.

Figures 2 and 3 show the results of the studies performed on board veneered on both sides. Beech ve- 
African ebony - $11.8 \%$ / Beech $-12.8 \%$
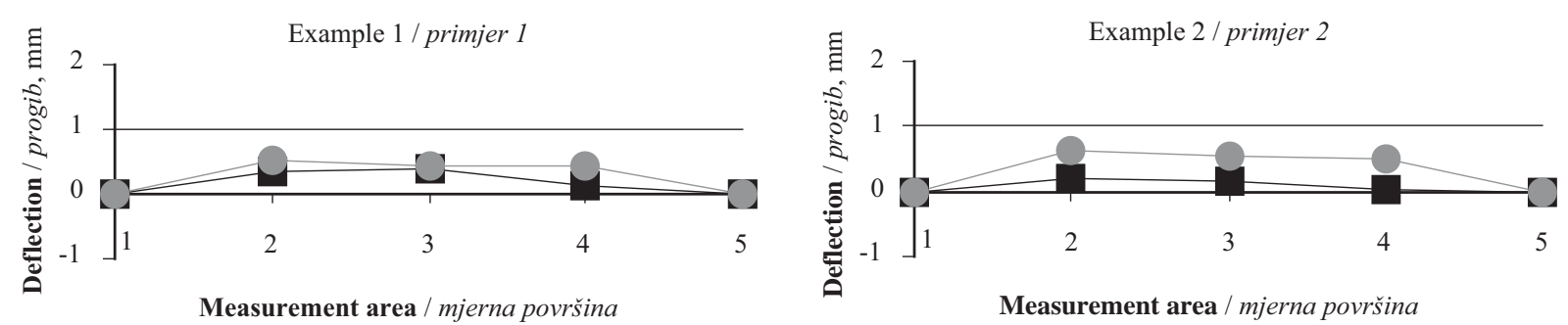

Figure 2 Deflection of the board asymmetrically veneered on both large sides - small difference of shrinkage values Slika 2. Progib ploče koja je asimetrično furnirana s obje strane - mala razlika između vrijednosti utezanja

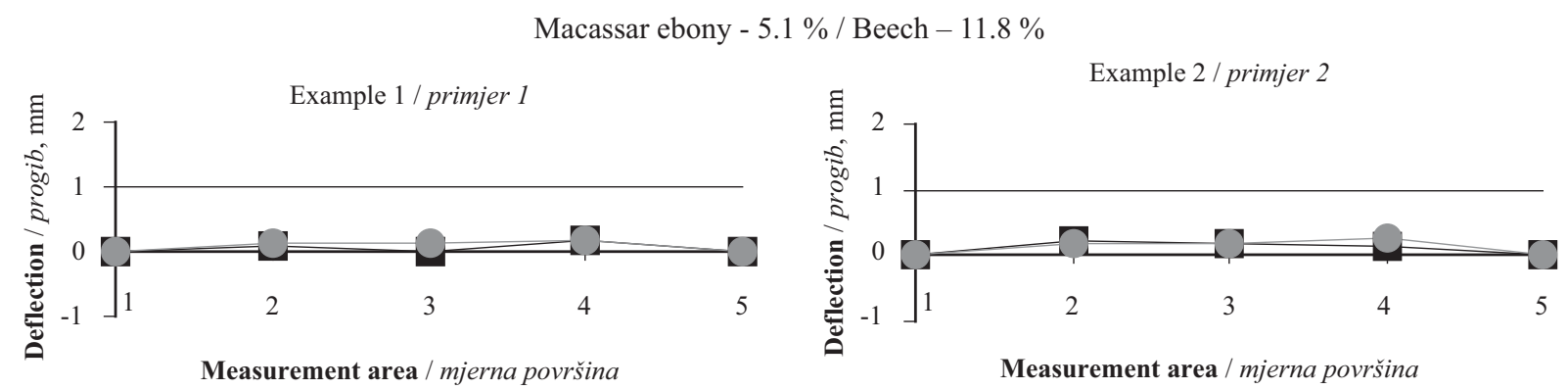

Figure 3 Deflection of the board asymmetrically veneered on both large sides - significant difference of shrinkage values Slika 3. Progib ploče koja je asimetrično furnirana s obje strane - značajna razlika između vrijednosti utezanja

neer (Fagus sylvatica L.) is on one side. Figure 2 shows examples of the results obtained for the board veneered with African ebony (Diospyros spp. Hiern) on the other side - small difference of shrinkage values. Figure 3 shows examples of the results for the board veneered with Macassar ebony (Diospyros celebica Bakh.) on the other side - significant difference of shrinkage values.

The results of these studies show that the chosen glue provides shape stability after the process of bothside asymmetrical veneering, even if the shrinkage difference was high, and the values of deformations were low. At the critical point of deformation, boards 1 and 2 reached $0.51 \mathrm{~mm}$ and $0.61 \mathrm{~mm}$, respectively.

Larger geometric deformations of boards 1 and 2, even for small difference of shrinkage values, can be explained by differences in the porosity of veneers. In boards 1 and 2, the porosity difference between African ebony and beech was $35 \%$. In boards 1 and 2, the porosity difference between Macassar ebony and beech was only $13 \%$. Thus, it seems that porosity, apart from shrinkage, is one of the main factors determining stability of asymmetrical veneered panels.
Figure 4 shows the results of the studies made on one-side veneered board using beech veneer - large difference of shrinkage values. The following variables were used:

- - difference between unveneered board and one-side veneered board, unvarnished,

- - difference between unveneered board and one-side veneered board, varnished.

The results of these studies show that the examined adhesive provides stability of shape of the samples after veneering. Another advantage of the elastic glue bond line is small geometric deformation. At the critical point, deformation reached $0.37 \mathrm{~mm}$.

\section{CONCLUSION \\ 4. ZAKLJUČAK}

Samples veneered with elastic glue joint preserve their shape, or their deflection is small. Therefore, obviously the properties of glue joint contribute much to the level of geometric deformations of the board.

Studies show that shrinkage in hardwood species does not have an influence on deformations in the ve-
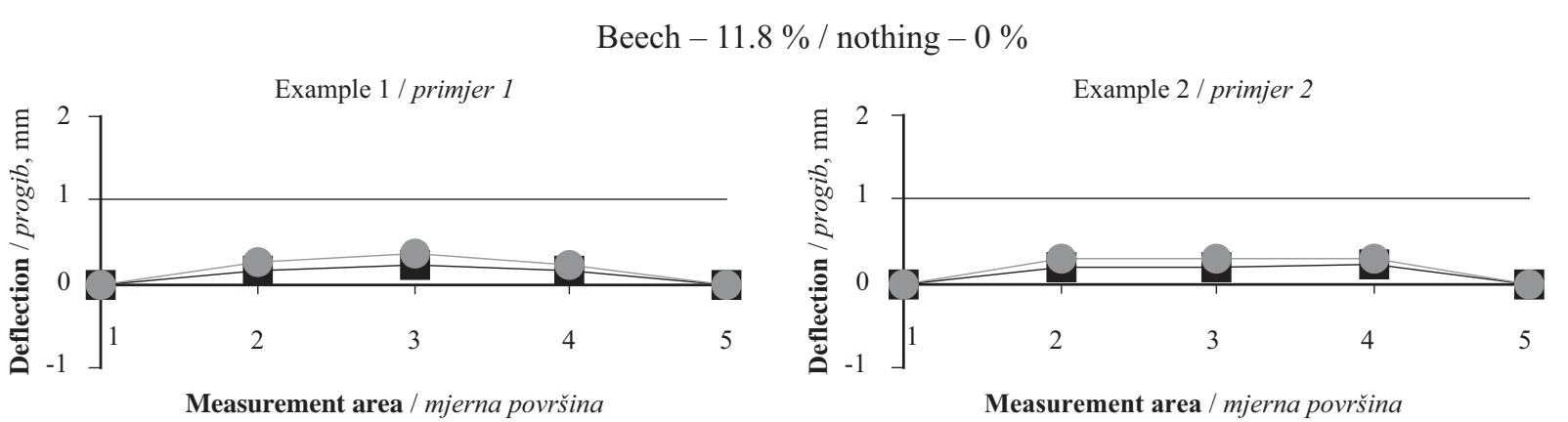

Figure 4 Deflection of boards asymmetrically veneered on one large side - large difference of shrinkage values Slika 4. Progib ploča koje su asimetrično furnirane s obje strane - velika razlika između vrijednosti utezanja 
neered board. The porosity of species used was the main factor affecting the deformations of asymmetrically veneered boards.

A high difference in porosity values causes higher geometric deformations of asymmetrically veneered boards. This can be solved by using optimised technology of gluing and varnishing.

\section{Acknowledgement - Zahvala}

This paper was financially supported by the National Sciences Centre within the project No. DEC2011/01/N/ST8/07752. The results were presented at the $20^{\text {th }}$ IWMS in Sweden.

\section{REFERENCES}

\section{LITERATURA}

1. EN 13556: 2003 Round and sawn timber- Nomenclature of timbers used in Europe

2. Hayward, C., 1949: Practical veneering. Bell \& Hyman. London.

3. Jakubiak, J.; Linden, L. A., 2001: Contraction (shrinkage) in polymerization. Fundamentals and measurements (in polish). Polimery 46: 522-528.

4. Kokociński, W., 2004: Wood. Measurements of physical and mechanical properties (in polish). PRODRUK. Poznań.

5. Konnerth, J.; Gindl, W., 2006: Mechanical characterisation of wood - adhesive interphase cell walls by nanoindentation. Holzforschung 60: 429-433 http://dx.doi.org/10.1515/HF.2006.067.

6. Konnerth, J.; Gindl, W.; Mueller, U., 2007: Elastic Properties of Adhesive Polymers I. Polymer Films By Means of Electronic Speckle Pattern Interferometry. Journal of Applied Polymer Science 103: 3936-3939

http://dx.doi.org/10.1002/app.24434.

7. Negri, M.; Sandak, J.; Kowaluk, G.; Pałubicki, B., 2009: Form and mass changes of composite panels under variable environment humidity. Drewno-Wood 182: 7-16.

8. Oleńska, S.; Mamiński, M.; Beer, P., 2012: Determination of contact angle values of glues with various gluejoint properties. Proceedings of $8^{\text {th }}$ International science conference Chip and chipless woodworking processes, Technical University in Zvolen, Faculty of Wood Sciences and Technology, Zvolen, Slovakia 2012: 261-266.
9. Oleńska, S.; Roszkowski, M.; Cichy, A.; Beer, P., 2010: Analysis of geometrical deformations of furniture fronts. Annals of Warsaw University of Life Sciences-SGGW, Forestry and Wood Technology 72: 90-94.

10. Oleńska, S.; Tarcicki, P.; Mamiński, M.; Beer, P., 2011b: Wood-based panels veneered with different hardwoods in room temperature. Annals of Warsaw University of Life Sciences - SGGW. Forestry and Wood Technology 75 : 163-168.

11. Oleńska, S., Tarcicki, P.; Cichy, A.; Mamiński, M.; Beer, P., 2011c: Asymmetrical Veneering with Hardwood Species of Different Shrink Value. Proceeding of the $20^{\text {th }}$ International Wood Machining Seminar, Skelleftea, Sweden, 2011: 543-547.

12. Oleńska, S.; Wozniak, M.; Mamiński, M.; Beer, P., 2011a: Influence of varnishing with acrilate resin on geometrical stability of furniture fronts veneered with African pterygota (Pterygota bequaertii De Wild.) Annals of Warsaw University of Life Sciences - SGGW. Forestry and Wood Technology 75: 160-163.

13. Ostrowski, A.; Roszkowski, M., 2009: Draft Analysis of one-side veneered element's deformations, Wood Research Slovakia (in print).

14. Papadopoulos, A. N.; Hill, C. A. S.; Traboulay, E.; Hague, J. R. B., 2002: Isocyanate Resins for Particleboard: PMDI us EMDI. Holz als Roh- und Werkstoff 107: 0275.

15. PN-EN ISO 868:2005P: Plastics and ebonite. Determination of indentation hardness by means of a durometer (Shore hardness).

16. BS ISO 7619-1: 2010: Rubber, vulcanized or thermoplastic. Determination of indentation hardness durometer method (Shore hardness).

\section{Corresponding address:}

Prof. PIOTR BEER, Ph.D.

Faculty of Wood Technology

Warsaw University of Life Sciences

Department of Technology, Organization

and Management in Furniture Industry

Nowoursynowska Street 159

02-776 Warszawa, POLAND

e-mail: piotr.beer@onet.pl 